\title{
Feeding ecology of the velvet swimming crab Necora puber in mussel raft areas of the Ría de Arousa (Galicia, NW Spain)
}

\author{
Juan Freire, Eduardo González-Gurriarán \\ Departamento de Bioloxía Animal e Bioloxía Vexetal, Universidade da Coruña, Campus da Zapateira s/n, \\ E-15071 A Coruña, Spain
}

\begin{abstract}
The feeding ecology of the velvet swimming crab Necora puber (Decapoda: Portunidae) in 3 mussel raft culture areas of the Ría de Arousa (Galicia, NW Spain) was studied through the analysis of stomach contents. The dominant prey was Pisidia longicornis (50 to $81 \%$ of the diet in the different areas), a small epifaunal anomuran crab that inhabits culture ropes. Other important food components were brachyuran crabs, the mussel Mytilus galloprovincialis and other bivalves, gastropods, egg cases of the gastropod Nassa spp., the echinoid Psammechinus miliaris and fishes. Plants (both eelgrass and seaweeds), sponges and polychaetes constituted secondary prey, with low quantitative importance. Habitat was the most important factor in diet variability within the ria, related to the spatial differences in abundance and structure of the benthic and raft epifaunal communities. Also, important differences were observed between the diet in soft bottom areas of the Ría de Arousa and rocky zones in other geographical areas, where the importance of seaweeds was higher. The diet of $N$. puber was dominated by raft epifauna and mussels, and also by the megabenthos. Macroinfauna and plants showed little quantitative importance. For the epifaunal prey, P. longicornis was selected positively and amphipods negatively; in the case of the infauna, bivalves and ophiuroids were selected positively, and polychaetes negatively. Diet variability related to life history was due mainly to ontogenetic changes. Fishes, brachyurans, mussels, echinoids and sponges increased their contribution to the diet with growth, but $P$. longicornis, egg cases of Nassa spp., and the holothurian Aslia lefevrei presented the opposite pattern. The relationship between body size and gut fullness presented a negative allometry, but absolute food consumption increased with size. Food consumption variability was linked mainly to intermoult stage and season. During the immediate premoult and postmoult, there was no food ingestion; however, gut fullness was higher in the recent postmoult compared to intermoult animals. Seasonal changes were due to higher food consumption in autumn and winter.
\end{abstract}

KEY WORDS: Feeding - Diet - Mussel culture - Ría de Arousa - Necora puber Portunidae

\section{INTRODUCTION}

The velvet swimming crab Necora puber (Decapoda: Portunidae) is an abundant species in the subtidal rocky zones of the northeast Atlantic (González-Gurriarán \& Méndez 1985), where it may be one of the dominant epibenthic predators regulating the abundance and distribution of the prey populations (Kitching et al. 1959, Muntz et al. 1965, Aronson 1989, 1992). Earlier studies in rocky intertidal and subtidal zones indicate that the diet composition and food consumption of this species are highly variable, both spatially (along the depth gradient) and seasonally, as well as over the crab's life history (reproductive and intermoult cycles) (Choy 1986, Norman \& Jones 1992).

Mussel culture is becoming increasingly important worldwide, causing major changes in the ecosystem (Veer 1989, Smaal 1991). In the rías of the coast of Galicia (NW Spain), the culture of Mytilus galloprovincialis on rafts has brought about changes in the structure of the pelagic (Corral \& Alvarez-Ossorio 1978) and benthic (Tenore et al. 1982) food webs. The production of pseudofaeces by the mussel and the 3-dimensional habitat made up of the culture ropes has led to the 
development of an epifaunal and macroalgal community that reaches a high biomass (Lapointe et al. 1981, González-Sanjurjo 1982, Román \& Pérez 1982, Fernández et al. 1990). On the other hand, the accumulation of biodeposits on the bottom has modified the characteristics of the sediment and has led to a decrease in infaunal diversity and biomass (López-Jamar 1982, Tenore et al. 1982). The production and biomass of the megabenthos, particularly of decapod crustaceans, are higher in the culture areas, as compared to other rías and other habitats within the Ría de Arousa (Chesney \& Iglesias 1979, Iglesias 1981, González-Gurriarán 1982, Olaso 1982, Romero et al. 1982).

There is an important trap fishery for Necora puber on the rocky subtidal zones of Galicia. However, the new soft substrate habitats created in the mussel culture zones have been occupied by the velvet swimming crab, giving rise to high population densities and to the creation of a new trawl fishery (González-Gurriarán 1981, 1985a, b). N. puber is one of the dominant species within the megabenthic community, especially in the outer area of the Ría de Arousa. Preliminary studies pointed to the influence that the culture has on diet composition (González-Gurriarán 1978); these studies do not, however, deal with the different aspects of $N$. puber feeding ecology.

This study examines the feeding ecology of Necora puber in the mussel culture areas in the Ría de Arousa, based on the hypothesis that distribution and abundance patterns are associated with changes in diet composition. The crab's feeding habits, its seasonal and spatial changes, and the variability related to the life history are determined through the analysis of stomach contents.

\section{MATERIAL AND METHODS}

Study area. Three mussel culture areas which are characteristic of the biotic and environmental variability that exists in the ria within the raft polygons were sampled (Fig. 1) (González-Gurriarán 1982, LópezJamar 1982, Román \& Pérez 1982, Tenore et al. 1982). The bottoms of the culture areas receive a great amount of material and organisms from the rafts (mussel and associated epifauna, macroalgae, remains of culture ropes, etc.), which generate shelter and microhabitats for the mobile epifauna. Stn B1, which is found in the inner ría area, is 10 to $15 \mathrm{~m}$ deep, has salinity fluctuations due to the river runoff, and a muddy bottom which is sometimes anoxic (López-Jamar 1982). Stn B5 is located in the mid-outer zone which is subject to oceanic influence, with a depth of 20 to $30 \mathrm{~m}$ and a sandy-muddy bottom. Stn B6 is located on the southeast side of the ria and is mainly used for mussel culture, although some of the rafts are used to culture oysters. The depth in this zone ranges between 10 and $20 \mathrm{~m}$, with a sandymuddy bottom and a great abundance of green seaweeds in spring and summer. This area has a mixture of characteristics typical of the beach areas and raft culture zones.

Sampling. Samples were taken using

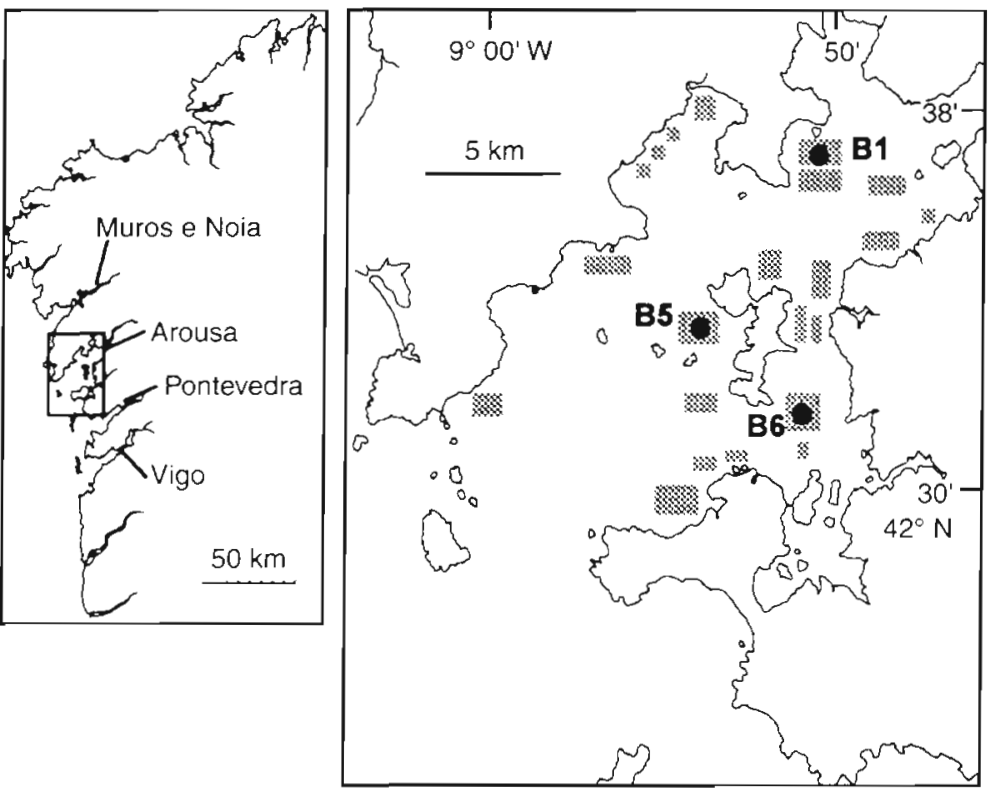

Fig. 1. Coast of Galicia (NW Spain). Ría de Arousa. Location of sampling stations (-) and areas where mussel raft culture is carried out within the ria (shaded areas) a beam trawl having an opening of $4 \mathrm{~m}$ and a cod-end mesh of $10 \mathrm{~mm}$ (GonzálezGurriarán 1982). A preliminary study was carried out to analyze the diel pattern of feeding activity and to determine the subsequent sampling strategy. Sampling was carried out over a $24 \mathrm{~h}$ cycle in April 1989 at Stns B1 and B5. At each station three 10 min tows were taken at $6 \mathrm{~h}$ intervals. The 3 stations were sampled monthly from July 1989 to June 1990 with the exception of December due to inclement weather conditions. Each month 3 to 5 tows were carried out at each station over a $2 \mathrm{~d}$ period (between 08:00 and 15:00 h). After each tow the samples were fixed in $4 \%$ neutralized formalin, and after 24 to 48 h were stored in $70 \%$ alcohol.

Laboratory methods. The following data were recorded for each crab: carapace width (CW, from the extremes of the fifth pair of anterolateral spines of the 
cephalothorax); wet weight (dry weight was calculated using the conversion factor obtained by GonzálezGurriarán 1982); sex; and in females, the presence of eggs in the abdomen was determined, as well as the gonad maturity stage following criteria of GonzálezGurriarản (1985a) and Choy (1988) (stage I, ovaries at rest; stage II, beginning of maturation; stage III, mature ovaries in active development; stage IV, fully developed ovaries, immediately prior to spawning). The stage of the intermoult cycle was determined based on the calcification level in the exoskeleton: stage $A$, immediate postmoult, very soft exoskeleton (stage $A_{1}$ from Drach \& Tchernigovtzeff 1967); stage B, when calcification begins and the exoskeleton has a paperlike consistency $\left(A_{2}\right.$ to $\left.B_{2}\right)$; stage $C$, advanced postmoult, where the exoskeleton is only flexible in the pterigostomial region of the carapace $\left(\mathrm{C}_{1} \text { and } \mathrm{C}_{2}\right)_{i}$ stage IM, intermoult, the exoskeleton is rigid and hard $\left(C_{3}\right.$ to $\left.D_{1}\right)$; and stage $D$, premoult, the new exoskeleton is almost completely formed underneath the old one $\left(\mathrm{D}_{2}\right.$ to $\left.\mathrm{D}_{4}\right)$.

The different prey found in the stomach contents were determined at the lowest taxonomic level possible under a binocular microscope. In cases where more than 1 food component was found in the stomach contents, the relative importance of the different prey was determined using the points method. This method estimates the food volume with respect to the total stomach volume (maximum 100) and the assigned value is divided among the different prey in terms of the volume of the stomach content that they occupy (Williams 1981). Given the fragmentation of the prey, it was only possible to determine the number of specimens of each prey per stomach in part of the contents analyzed. Stomach fullness was estimated by means of both the points method and dry weight of the food (to the nearest $1 \mathrm{mg}$ ).

Data analysis. Stomach fullness is described by the percentage of stomachs with food, points index, and the BDW index: BDW $=($ Food dry weight/Body dry weight $\times 100$. The importance of the different food components in the diet was estimated by means of the following indices:

- Frequency of appearance index: $F_{i}=\left(n_{i} / N\right) \times 100$, where $\mathrm{n}_{1}$ is the number of stomachs containing prey $i$ and $\mathrm{N}$ is the number of stomachs with food analyzed; - Points index: $\mathrm{IP}_{i}=\left(\Sigma \mathrm{P}_{i j} / \Sigma \mathrm{P}_{j}\right) \times 100$, where $\mathrm{P}_{i j}$ is the value in points of prey $i$ in stomach $j$, and $\mathrm{P}_{j}$ is the total number of points for stomach $j$; and

- Percentage of the BDW fullness index corresponding to each prey: $\mathrm{BDW}_{i}=\left(\Sigma \mathrm{BDW} W_{i j} / \Sigma \mathrm{BDW}_{j}\right) \times 100$, where $\mathrm{BDW}_{i}$ is the percentage of body dry weight corresponding to prey $i$ in stomach $j$, and $\mathrm{BDW}_{j}$ is the percentage of body dry weight corresponding to the total food for specimen $j$. Where stomachs showed more than 1 prey, BDW was estimated from BDW, and the value in points assigned to each prey.

In the study of the diel cycle, the differences in fullness level between hours at each station were tested using analysis of covariance (ANCOVA) [variable: $\log _{10}$ (Food dry weight +0.001$)$; covariate: $\log _{10}$ (Body dry weight)]. The diel differences in the consumption of the different prey (measured as BDW) were analyzed using Kruskal-Wallis tests.

The analysis of the influence of different factors on the consumption of each prey was carried out by fitting log-linear models by the maximum likelihood method to contingency tables made up of the following variables: prey (presence/absence), station, sex, intermoult stage (B, C and IM) and body size classes. Loglinear models have also been used to analyze the variability in the number of different food components per stomach. Diet diversity was estimated using the Shannon-Wiener index $\left(H^{\prime}\right)$ and the variance was calculated according to Magurran (1989).

The relationships between diet composition and variables linked to the life history and environmental variables ('external variables') were determined using canonical correspondence analysis (CCA) (Ter Braak 1986, Ter Braak \& Prentice 1988). For this purpose matrices of prey and external variables were analyzed, which included data from crabs having food in the stomach. The variables for the prey matrix are the diet components, presenting information on the presence or absence in each stomach. The matrix of external variables is composed of body size, sex (coded as a nominal variable with 3 categories: $M$, males; $F$, non-ovigerous females; $O$, ovigerous females), intermoult stage (coded as a nominal variable with 3 classes B, C and IM), and sampling station (each station is represented by a nominal variable). Partial CCAs were also carried out (Ter Braak 1987, Walker et al. 1991, Kingston et al. 1992) to test the influence of each external variable on diet composition, after eliminating the effect of the other variables introduced into the analysis as covariates (stomach fullness was also included, represented by the points index and food dry weight). The statistical significance of the effect of the variable tested was analyzed by Monte-Carlo randomization tests, in which 99 unrestricted permutations were carried out on the original matrices. The multivariate analyses were done with the software CANOCO v. 3.12 (Ter Braak 1988).

The Ivlev index of electivity was used to compare the importance of the different prey in the stomach contents and in the field (Ivlev 1961): $E=(d-c) /(d+c)$, where $d$ is the proportion of the diet made up of a given prey, and $c$ is the importance in number or biomass of the same prey in the field. 
The relationship between body size and fullness was analyzed fitting the log-transformed allometric equation by least squares regression: Food dry weight $=$ ${ }_{a} \mathrm{CW}^{b}$. The differences in stomach fullness $\left[\log _{10}\right.$ (Food dry weight +0.001$)$ ] between sexes, intermoult stages and stations were analyzed by means of ANCOVAs.

\section{RESULTS}

\section{Diet composition and spatial changes}

Forty-eight different prey taxa were identified in the stomach contents of Necora puber, which were grouped into 19 categories in terms of importance in the diet and by morphological and biological characteristics (Table 1). Habitat was the most important factor in the diet variability of $N$. puber; the frequency of appearance of the dominant diet components showed significant differences between stations (Table 2 ; the results of the fitting of the log-linear models suggest that the factors analyzed represented effects which are independent, since only Brachyura and Pisidia longicornis have significant third order associations, although the significance level is generally lower than in second order interactions, $0.01<p<0.05$ ). The anomuran decapod $P$. longicornis was the main prey in all of the areas studied. The consumption of this prey exhibits significant differences between stations ( $\mathrm{p}<$ 0.001 ), reaching $81 \% \mathrm{BDW}$ at Stn B5. Brachyuran crabs were rather important at Stn B6, showing significant differences between stations $(p<0.05)$. Within the molluscs, Mytilus galloprovincialis was the most important prey, especially at Stn B1 where it appeared in $24 \%$ of stomachs with food ( $p<0.05$ ). The egg cases of the gastropod Nassa spp. were another important item in the diet at Stns B1 and B5; they were not consumed, however, at Stn B6. Teleost fishes make up

Table 1. Necora puber. Diet composition at the different sampling stations using the indices BDW, points (IP) and frequency of appearance (F); see 'Materials and methods: Data analysis'. Diet diversity for each station and index is shown. Number analyzed vs number with food given in parentheses after station number

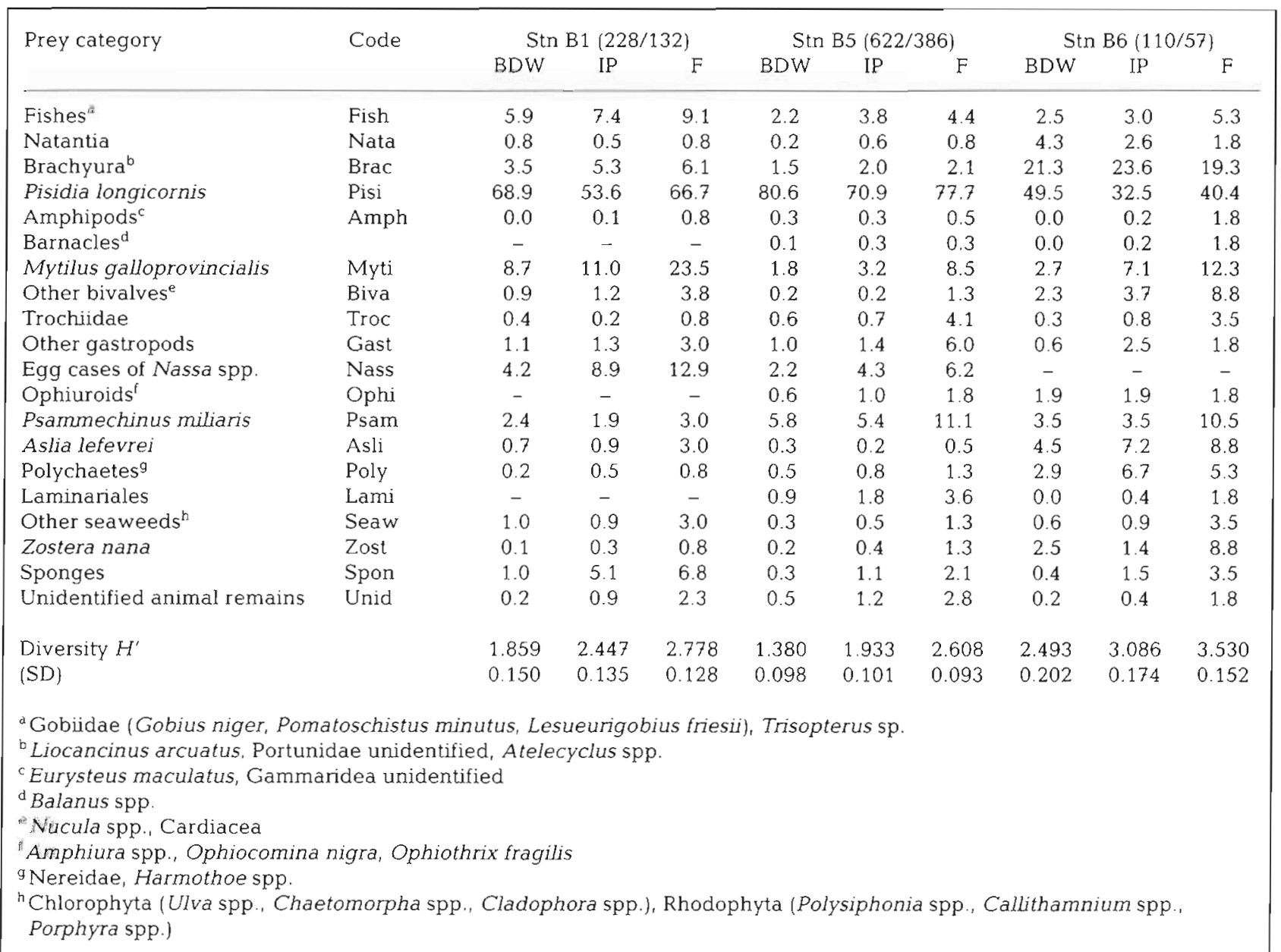


Table 2. Necora puber. Analysis of the consumption of the different prey using log-linear models fitted to contingency tables. Model design is Prey (2) $\times$ Station (3) $\times$ Intermoult stage (3) $\times$ Sex (3) $\times$ Size (7) (the number of levels is indicated in parentheses). Statistical significance (p) of the $\chi^{2}$ statistic for partial association between factors is shown (in bold the effects with $p<0.05$ ). Fourth order interactions have been omitted as they presented non-significant effects in all cases $(p>0.05)$. Prey codes given in Table 1

\begin{tabular}{|c|c|c|c|c|c|c|c|c|c|}
\hline & df & Fish & Nata & Brac & Pisi & Myti & Biva & Troc & Gast \\
\hline Prey $\times$ Station $\times$ Intermoult & 4 & 0.932 & 1.000 & 0.535 & 0.093 & 0.214 & 0.085 & 0.230 & 1.000 \\
\hline Prey $\times$ Station $\times$ Sex & 4 & 0.724 & 0.632 & 0.035 & 0.212 & 0.717 & 0.683 & 0.164 & 0.090 \\
\hline Prey $\times$ Intermoult $\times$ Sex & 4 & 0.996 & 1.000 & 0.248 & 0.882 & 0.545 & 0.625 & 0.732 & 0.714 \\
\hline Prey $\times$ Station $\times$ Size & 12 & 0.530 & 0.865 & 0.021 & 0.187 & 0.733 & 0.238 & 0.682 & 0.161 \\
\hline Prey $\times$ Intermoult $\times$ Size & 12 & 0.985 & 1.000 & 0.592 & 0.011 & 0.895 & 0.661 & 0.932 & 0.645 \\
\hline Prey $\times$ Sex $\times$ Size & 12 & 0.999 & 0.994 & 0.999 & 0.097 & 0.817 & 0.999 & 0.911 & 0.159 \\
\hline Prey $\times$ Station & 2 & 0.267 & 0.792 & $<0.001$ & $<0.001$ & 0.011 & 0.011 & 0.151 & 0.127 \\
\hline Prey $\times$ Intermoult & 2 & 0.006 & 0.138 & 0.419 & 0.184 & 0.072 & 0.677 & 0.548 & 0.269 \\
\hline Prey $\times$ Sex & 2 & 0.283 & 0.744 & 0.003 & 0.023 & 0.936 & 0.838 & 0.594 & 0.379 \\
\hline \multirow[t]{2}{*}{ Prey $\times$ Size } & 6 & 0.004 & 0.546 & 0.024 & $<0.001$ & $<0.001$ & 0.748 & 0.130 & 0.063 \\
\hline & $\mathrm{df}$ & Nass & Psam & Asli & Poly & Lami & Seaw & Zost & Spon \\
\hline Prey $\times$ Station $\times$ Intermoult & 4 & 0.749 & 0.217 & 0.671 & 0.991 & 0.759 & 0.437 & 0.999 & 1.000 \\
\hline Prey $\times$ Station $\times$ Sex & 4 & 0.905 & 0.200 & 0.799 & 0.967 & 1.000 & 0.246 & 0.946 & 0.165 \\
\hline Prey $\times$ Intermoult $\times$ Sex & 4 & 0.369 & 0.791 & 1.000 & 0.668 & 0.310 & 0.844 & 1.000 & 1.000 \\
\hline Prey $\times$ Station $\times$ Size & 12 & 0.898 & 0.691 & 0.998 & 0.930 & 0.988 & 0.946 & 0.794 & 0.596 \\
\hline Prey $\times$ Intermoult $\times$ Size & 12 & 0.351 & 0.643 & 0.607 & 0.785 & 0.817 & 0.996 & 0.993 & 1.000 \\
\hline Prey $\times$ Sex $\times$ Size & 12 & 0.211 & 0.888 & 1.000 & 0.992 & 0.992 & 0.999 & 0.732 & 1.000 \\
\hline Prey $\times$ Station & 2 & 0.001 & 0.010 & 0.001 & 0.106 & 0.018 & 0.213 & 0.002 & 0.548 \\
\hline Prey $\times$ Intermoult & 2 & 0.272 & 0.245 & 0.405 & 0.963 & 0.003 & 0.248 & $<0.001$ & 0.001 \\
\hline Prey $\times$ Sex & 2 & 0.310 & 0.085 & 0.007 & 0.637 & 0.840 & 0.434 & 0.117 & 0.071 \\
\hline Prey $\times$ Size & 6 & 0.038 & 0.560 & 0.134 & 0.073 & 0.234 & 0.052 & 0.755 & 0.006 \\
\hline
\end{tabular}

between 2 and $6 \%$ BDW at the different stations. The echinoid Psammechinus miliaris was one of the main prey at Stn B5, showing significant differences between areas $(p=0.01)$. The holothuroid Aslia lefevrei had some quanitative importance at Stn B6, whereas at Stns B1 and B5 it did not exceed 1\% BDW $(\mathrm{p}=0.001)$. The following prey were secondary components in the diet $(<3 \% \mathrm{BDW})$ : polychaetes and the eelgrass Zostera nana (both consumed mainly at Stn B6), seaweeds and sponges. The remains of unidentifiable food in the stomachs constituted 0.2 to $0.5 \%$ BDW of the diet (appearing in $<3 \%$ of stomachs). Stn B5 had lower diversity values than those at Stns B1 and B6, which may be attributed to the greater importance of $P$. longicornis at Stn B5 (Table 1).

\section{Diel patterns of feeding activity}

The stomach fullness of Necora puber throughout the diel cycle ranged between 0.24 and $0.35 \%$ BDW (26 to $32 \%$ points) at Stn B5 and between 0.16 and $0.54 \%$ BDW (27 to $43 \%$ points) at Stn B1 (Fig. 2). There was high variability within each sample and no significant differences in repletion level were observed between times at any of the stations (ANCOVA, $p>0.1$ for the effects of time and body dry weight at Stns B1 and B5). On the other hand, no significant differences were found in the diet composition throughout the diel cycle (Kruskal-Wallis tests, $p>0.05$ ), except in the case of the egg cases of Nassa spp. at Stn B5, which were consumed to a greater extent during the day $(p<0.001)$.

\section{Number of food components and prey specimens per stomach}

Of the stomach contents analyzed, $68.5 \%$ showed 1 type of prey, $22.5 \%$ exhibited 2 types, and $8.0 \%$ exhibited 3 and 4 types (only in 3 cases) (mean number of different prey per stomach: 1.41). The prey diversity per stomach varied according to the intermoult stage and size (log-linear model, $p<0.05)$, but not between stations or sexes $(p>0.05)$. Growth was associated with an increase in the diversity per stomach; crabs smaller and larger than $50 \mathrm{~mm} \mathrm{CW}$ had an average of 1.25 and 1.51 prey per stomach respectively. During the intermoult cycle the number of prey per stomach increased in stage $C(1.61)$ as compared to stages B and IM (1.35 and 1.37 respectively). 

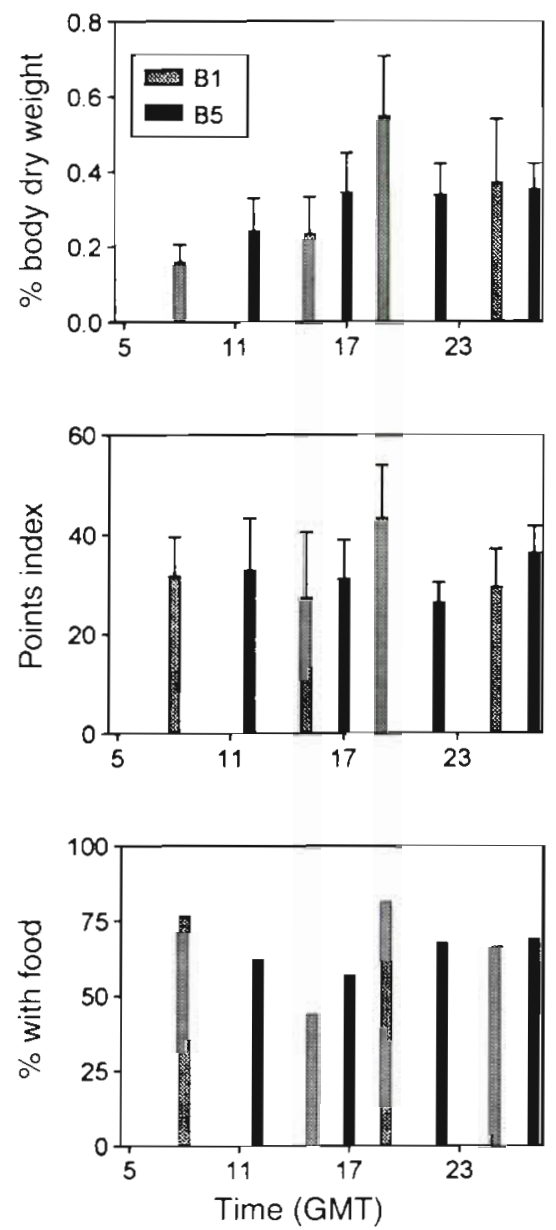

Fig. 2. Necora puber. Diel evolution of stomach fullness (estimated as BDW, points index and percentage of stomachs with food) at Stns B1 and B5. Standard error is shown for the points and BDW indices

Only in $27 \%$ of the cases was it possible to identify the number of specimens of each prey per stomach (excluding seaweeds, sponges and holothurians). Of the prey, $91 \%$ were represented by 1 specimen only, $6 \%$ by 2 , and $3.3 \%$ had 3 or more individuals. The results were very similar for all prey, with a slight increase in the percentage of stomachs with only 1 specimen in components having a larger body size (such as the fishes, Brachyura or Mytilus galloprovincialis).

\section{Comparative analysis of diet composition indices}

Points and BDW indices give a similar description of diet composition, although the points index increases, generally, the importance of the prey representing $<10 \%$ of the diet. However, there are major differences between the quantitative indices and frequency of appearance, especially in small-sized prey which are consumed on a regular basis but are of relatively minor quantitative importance (Table 1).

The points and BDW indices used in the quantitative estimate of diet composition were subjected to a comparative analysis. Seven dominant prey and stomach contents showing the remains of only 1 prey were chosen. The allometric equations fitted relating the 2 indices were significant in all cases and the slopes were always different from 1 ( $t$-test, $\mathrm{p}<0.05$ ) (Table 3 ). Both the sponges and Mytilus galloprovincialis $(b<1)$ appear in the stomach contents as non-skeletal tissue (in the mussel the volume of shell ingested was small compared to the mantle), whereas the remains of Psammechinus miliaris, Brachyura, Pisidia longicornis and fishes $(b>1.24)$ had a large amount of hard elements with a high dry weight:volume ratio.

\section{Differences in diet composition between sexes}

There were only minor differences in the diet between sexes. Non-ovigerous females consumed more Pisidia longicornis than males at the 3 stations (Table 2, p $<0.05$; Stn B1: $78 \%$ BDW in males and $62 \%$ in females; Stn B5: $86 \%$ and 75\%; Stn B6: $65 \%$ and $34 \%$ ). Males preyed largely on Brachyura especially at

Table 3. Necora puber. Relation between the BDW and points indices in terms of establishing the importance of the different prey in the diet. Parameters of the equation $\log _{10}\left(B D W_{1}\right)=\log _{10} a+b \log _{10}\left(I_{i}\right)$, fitted for the different groups of prey, the regression coefficient $\left(R^{2}\right)$ and their significance $(p)$ are indicated. Data from crabs having only 1 type of prey in their stomach contents were used

\begin{tabular}{|c|c|c|c|c|c|}
\hline Prey & $\log a(S E)$ & $b(\mathrm{SE})$ & $\mathrm{R}^{2}$ & $\mathrm{p}$ & $\mathrm{N}$ \\
\hline Fishes & $-3.721(0.382)$ & $1.433(0.236)$ & 0.770 & $<0.001$ & 13 \\
\hline Brachyura & $-4.128(0.444)$ & $1.610(0.259)$ & 0.708 & $<0.001$ & 18 \\
\hline Pisidia longicornis & $-3.500(0.097)$ & $1.245(0.060)$ & 0.613 & $<0.001$ & 278 \\
\hline Mytilus galloprovincialis & $-3.163(0.230)$ & $0.896(0.158)$ & 0.617 & $<0.001$ & 22 \\
\hline Egg cases of Nassa spp. & $-3.568(0.357)$ & $1.090(0.241)$ & 0.612 & 0.001 & 15 \\
\hline Psammechinus miliaris & $-3.481(0.448)$ & $1.399(0.330)$ & 0.750 & 0.005 & 8 \\
\hline Sponges & $-2.835(0.321)$ & $0.675(0.233)$ & 0.433 & 0.015 & 13 \\
\hline
\end{tabular}


Stns B1 and B6 ( $p<0.05$ in males, brachyuran remains represented $6 \%$ and $45 \%$ BDW at Stns B1 and B6 respectively, whereas in females, they were not present). The diet of ovigerous females did not show any major differences and the number of stomachs with food did not allow for a detailed analysis. The diversity of the diet was greater in males than females, especially at Stns B1 and B5, ranging from 1.64 to 2.14 for females at the different stations and from 1.08 to 1.91 for females.

\section{Changes in diet composition linked to the intermoult cycle}

There were significant changes between intermoult stages in the consumption of fishes, Laminariales, Zostera nana and sponges (Table 2, p < 0.05). A distinction can be made between those components consumed more by the recent postmoult stages B and C (fishes, Laminariales and $Z$. nana, and to a lesser extent, Pisidia longicornis), and those consumed more in intermoult (Mytlius galloprovincialis, sponges, egg cases of Nassa spp. and Psammechinus miliaris].

At Stn B1 the most important differences between intermoult stages were found in components that are of minor quantitative value in the diet. At Stn B6, Necora puber preyed during stage $B$ on Brachyura, ophiuroids, Aslia lefevrei, fishes and polychaetes, with a sharp drop in the consumption of Pisidia longiconis compared to stages $\mathrm{C}$ and IM $(21 \% \mathrm{BDW}$ in stage $\mathrm{B}$, $72 \%$ in $\mathrm{C}$ and $50 \%$ in IM). At Stn B5, the consumption of both Laminariales and Zostera nana gradually decreased over the postmoult period $3.9 \% \mathrm{BDW}$ for plants in stage B, $1.2 \%$ in $C$ and $0.5 \%$ in IM). As with plants, predation on fishes diminished during the intermoult period (maximum of $5.4 \% \mathrm{BDW}$ in stage $\mathrm{C}$ and minimum of $1.1 \%$ in IM). Additionally, Mytilus galloprovincialis, egg cases of Nassa spp., and sponges appeared to increase their contribution to the diet throughout the intermoult cycle. The intermoult cycle did not modify the diversity of the diet in the different stations.

\section{Ontogenetic changes in the diet}

Consumption of fishes, Brachyura, Mytilus galloprovincialis, Psammechinus miliaris and sponges increased with growth, whereas the importance in the diet of Pisidia longicornis, egg cases of Nassa spp., and Aslia lefevrei diminished with predator body size (Fig. 3). P. longicornis had a similar pattern at the 3 stations; its contribution decreased as the crab grew (Table 2, p $<0.001$ ), especially in specimens $\geq 70 \mathrm{~mm}$
CW. At Stn B5 it varied between $89 \%$ BDW in crabs $<30 \mathrm{~mm}$ and $57 \%$ in sizes of 70 to $79 \mathrm{~mm}$. Stns B1 and B6 present a more pronounced ontogenetic diet variability. In crabs $\leq 50 \mathrm{~mm}, P$. longicornis accounted for $>50 \%$ of the diet, whereas in the $\geq 70 \mathrm{~mm}$ size class it was reduced to $37 \%$ at Stn B1 and as low as $10 \%$ in crabs $>80 \mathrm{~mm}$ at Stn B6. The consumption of fishes at Stn B1 as well as Stn B5 increased with predator growth $(p<0.05)$, and they appeared exclusively in the stomach contents of crabs with a $\mathrm{CW} \geq 50 \mathrm{~mm}$ and reached their peak in individuals $\geq 80 \mathrm{~mm}$. The Brachyura present in the stomach contents appeared in crabs with a CW $\geq 40 \mathrm{~mm}$, and reached maximum values in individuals $>60 \mathrm{~mm}(p<0.05)$. The mussel became more important in the diet with growth ( $p<$ 0.001 ) and it was consumed in individuals with $\mathrm{CW}$ $>40 \mathrm{~mm}$ (Stns B1 and B5) or $50 \mathrm{~mm}$ (Stn B6). However, in crabs within these size ranges, no clear trend was observed. $P$. miliaris appeared in the stomach contents of crabs between 56 and $79 \mathrm{~mm} \mathrm{CW}$ at Stns B1 and B6. At Stn B5 it made up part of the diet of all the size classes, with values ranging between $2 \% \mathrm{BDW}$ in individuals $<30 \mathrm{~mm}$ and $18 \%$ in those between 70 and $79 \mathrm{~mm}$, although the differences are not significant $(p>0.05)$. The diet diversity increased with growth both at Stns B1 and B5, although at Stn B6 the Shannon index was similar in the different size classes, with the exception of an increase in the specimens of 70 to $79 \mathrm{~mm}$ (Fig. 4).

\section{Seasonal changes in diet composition}

The dominant food components did not show any major seasonal fluctuations. The seasonality of the catches of Necora puber did not allow us to carry out a detailed analysis of the temporal variation of the diet at Stns B1 and B6 (at Stn B1 catches in winter were very small, whereas at Stn B6 most of the crabs analyzed were caught from September to November, and to a lesser extent in March). The importance of Pisidia longicornis in the diet at Stn B1 ranged between $65 \%$ BDW in May and $92 \%$ in March, however there was no seasonal pattern. The predation on molluscs increased in summer, both for bivalves and gastropods. Mytilus galloprovincialis was of maximum importance in the diet from July to October (reaching 6\% BDW in August) and the minimum was reached from February to April $(<1.0 \%)$. Similarly, gastropods only made up part of the diet of $N$. puber in summer and spring at Stn B1, while at Stn B5 they had minimum values in winter, reaching $7 \%$ BDW in May. Egg cases of Nassa spp. were only consumed from April to October, reaching maximums in July and September. Psammechinus miliaris presented minimum contributions in the diet in 

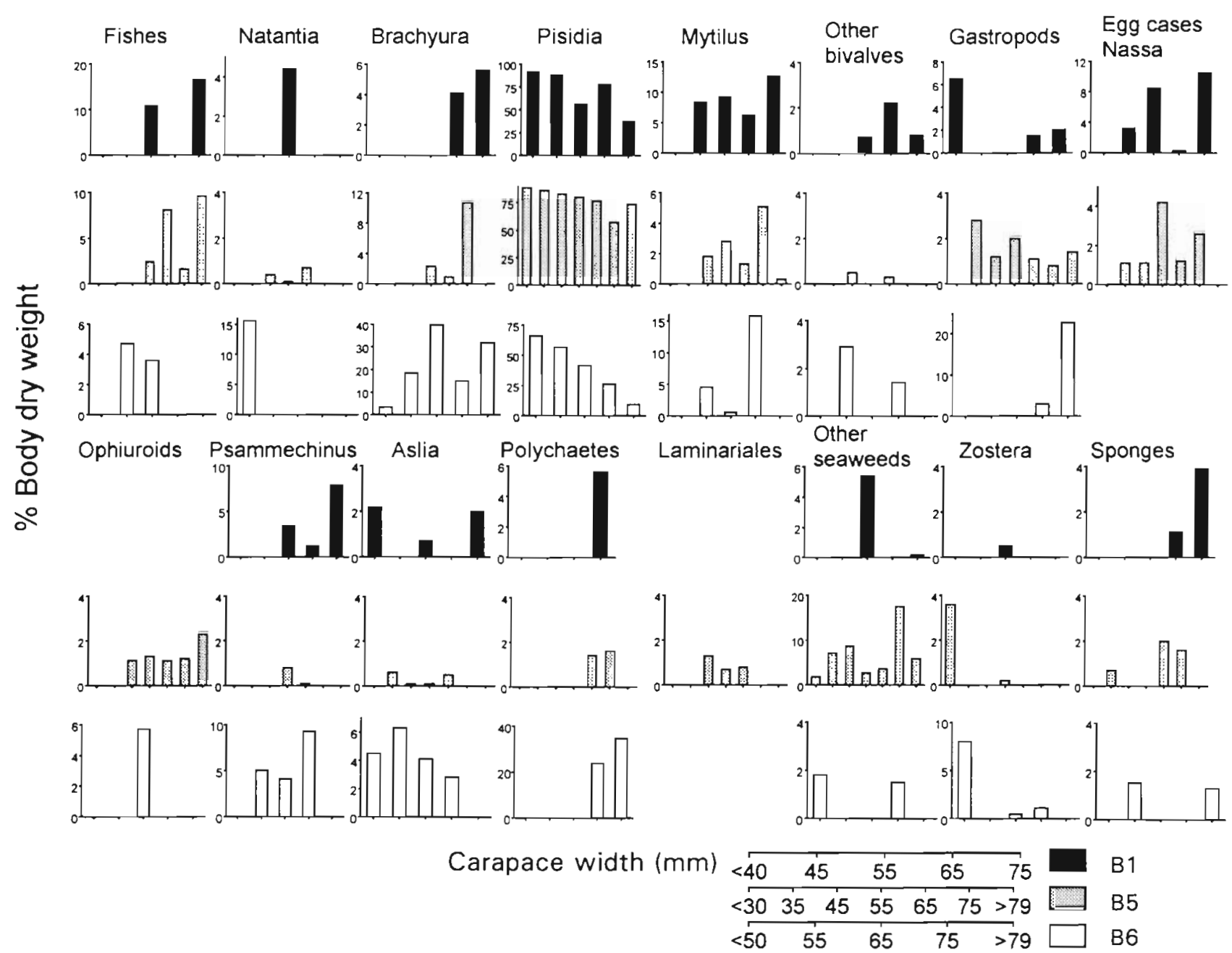

Fig. 3. Necora puber. Diet composition (BDW index) by body size class at Stns B1, B5 and B6. Note that the scales for each prey and station are different

winter and reached 19\% BDW in November. The brown seaweeds were clearly seasonal, making up part of the diet between November and April, with maximum values in January.

\section{Relation between sizes of predator and prey}

In general, the fragmentation of prey in the stomachs prevents the determination of their size. The size of Pisidia longicornis was estimated by the maximum width of its abdomen, which appeared either intact or fragmented in 2 pieces; maximum thickness of the shell remains of Mytilus galloprovincialis was estimated; the size of the gastropods of the family Trochiidae consumed was estimated by the diameter of the operculum which appears either intact or slightly fragmented. There was a significant positive relationship between predator (carapace width, $x$ ) and prey $(y)$ size in the case of $P$. longicornis $\left(y=0.092 x^{0861}, N=29, r=\right.$ $0.54, p<0.01$ ) and $M$. galloprovincialis $\left(y=0.009 x^{1340}\right.$, $\mathrm{N}=32, \mathrm{r}=0.50, \mathrm{p}<0.01)$ but not for Trochiidae $(\mathrm{N}=9$, $r=0.325, p>0.05)$.

\section{Multivariate analysis of diet composition}

The variance of the prey matrix explained by the axes extracted using the CCA was low (axis 1: 1.4\%) due to the fact that stomachs contained few and generally only 1 type of prey; however, the correlation between prey and external variables was high. Axis 1 $(\mathrm{r}=0.468 ; 36.4 \%$ of the variance of the prey-external variables relationship) correlates positively with size, and contrasts Stn B5 with Stns B1 and B6. Brachyura and sponges present positive scores, whereas the ophi- 

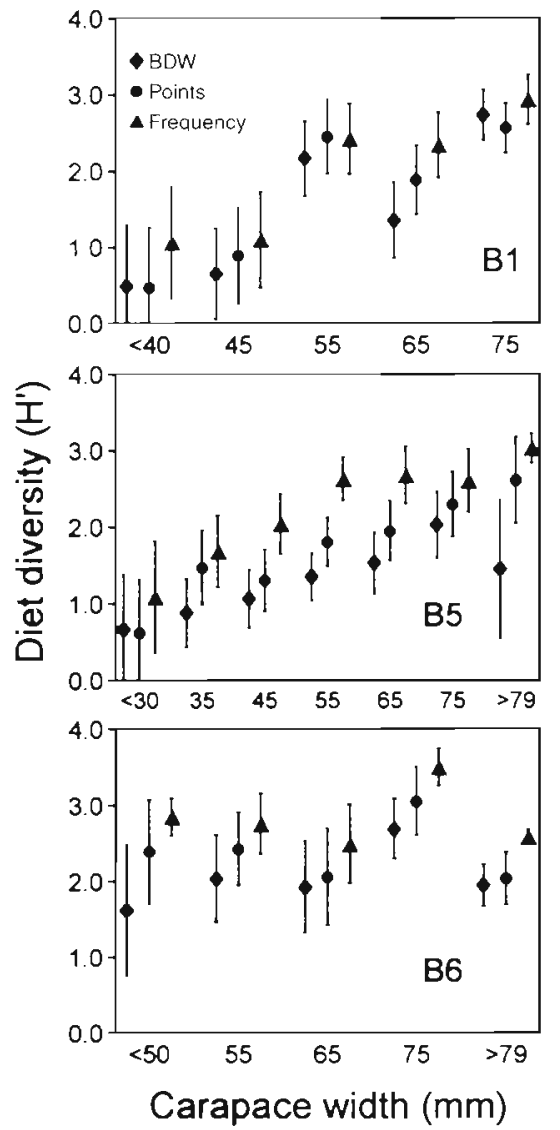

Fig. 4. Necora puber. Diet diversity (index $H^{\prime \prime}$ and $95 \%$ confidence interval) in the different size classes at each station, using different diet composition indices (BDW, points and frequency of appearance)

uroids, Natantia and Pisidia longicornis are arranged on the negative part of the axis (Fig. 5). Axis 2 ( $\mathrm{r}=$ $0.428 ; 30.0 \%$ variance) explains the changes in the diet which are linked to the intermoult cycle, with stage $B$ and prey such as Zostera nana, Aslia lefevrei and the Laminariales being on the positive end and others, such as the sponges, Mytilus galloprovincialis, gastropods or egg cases of Nassa spp., which are associ- ated with stage IM, on the negative part. Axis 3 (which corresponds only to $16.0 \%$ of the prey-external variables relationship) is associated mainly with the sta tion, although the correlations are lower than in axes 1 and 2. Axis 3 differentiates, on the one hand, Stn B5 and components such as Laminariales and Psammechinus miliaris and, on the other hand, Stn B1 and, to a lesser extent, Stn B6 which have prey such as Natantia, A. lefevrei or other bivalves

The partial CCAs show that all the factors analyzed have a significant effect on diet composition $(p=0.01)$, with the exception of $\operatorname{sex}(p=0.15)$. Eigenvalues of canonical axes show that station is the most important factor, and next in importance is size and the intermoult stage (Table 4). The partial CCA carried out to test the importance of stomach fullness on diet composition points to the existence of a significant effect ${ }_{i}$ in any case, the dominant prey do not present important scores on axis 1 . The prey having negative scores such as the group of other food items and unidentified remains, sponges, plants, gastropods and amphipods become less important in the diet as the fullness decreases, and therefore in stomachs in advanced stages of digestion. In contrast, Brachyura, ophiuroids, fishes, Psammechinus miliaris and Trochiddae continue to make up part of the stomach contents for a longer period of time.

\section{Stomach fullness}

There was a significant correlation between the level of stomach fullness, measured as food dry weight, and body size ( $p<0.05$, analyzing crabs with food in the stomach, except in ovigerous females) (Table 5). The slope of the fitted equations are always $<2$, which points to a negative allometric relationship, given that the slope of the size-weight relation for Necora puber in the Ría de Arousa is 2.96 in males and 2.88 in females (González-Gurriarán 1985b). Although the absolute fullness increased with body size, the relative BDW index decreased (Fig. 6). Significant differences

Table 4. Necora puber. Results of partial CCA in which the effect of the different external variables in the diet composition is tested after the other variables are introduced as covariates. $E_{1}, E_{2}$ : eigenvalues of canonical axes 1 and $2 ;$ r: correlation between the variables tested and the axis; $E_{c} / E_{n c}$ : relation between the sum of the eigenvalues for the canonical axes and the first non-

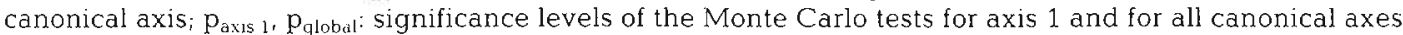

\begin{tabular}{|c|c|c|c|c|c|c|}
\hline Variable & Covariates & $E_{1}(r)$ & $E_{2}(r)$ & $E_{c} / E_{n c}$ & $p_{\text {axis } 1}$ & $\mathrm{p}_{\text {global }}$ \\
\hline Size & Station, Sex, Intermoult & $0.078(0.345)$ & - & 0.085 & 0.01 & - \\
\hline Sex & Size, Station, Intermoult & $0.041(0.251)$ & $0.009(0.122)$ & 0.054 & 0.03 & 0.15 \\
\hline Intermoult stage & Size, Station, Sex & $0.076(0.350)$ & $0.015(0.152)$ & 0.099 & 0.01 & 0.01 \\
\hline Station & Size, Sex, Intermoult & $0.117(0.421)$ & $0.051(0.305)$ & 0.182 & 0.01 & 0.01 \\
\hline Gut fullness & Size, Sex, Intermoult, Station & $0.057(0.283)$ & $0.033(0.234)$ & 0.099 & 0.01 & 0.01 \\
\hline
\end{tabular}



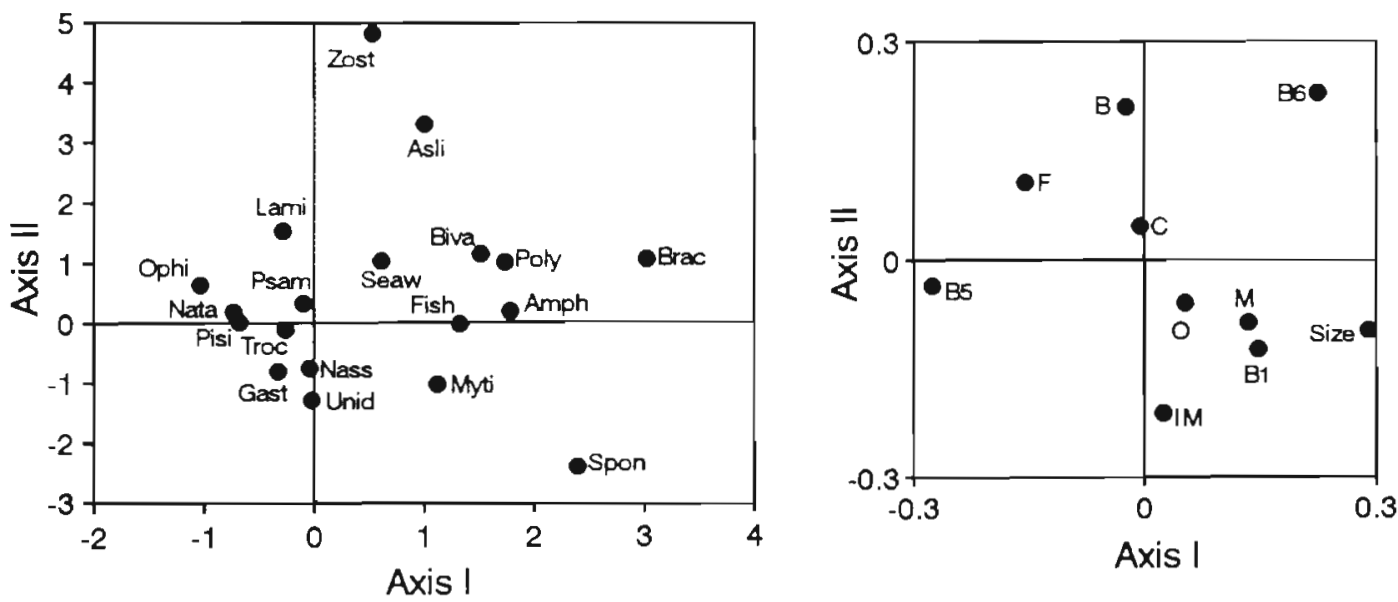

Axis I
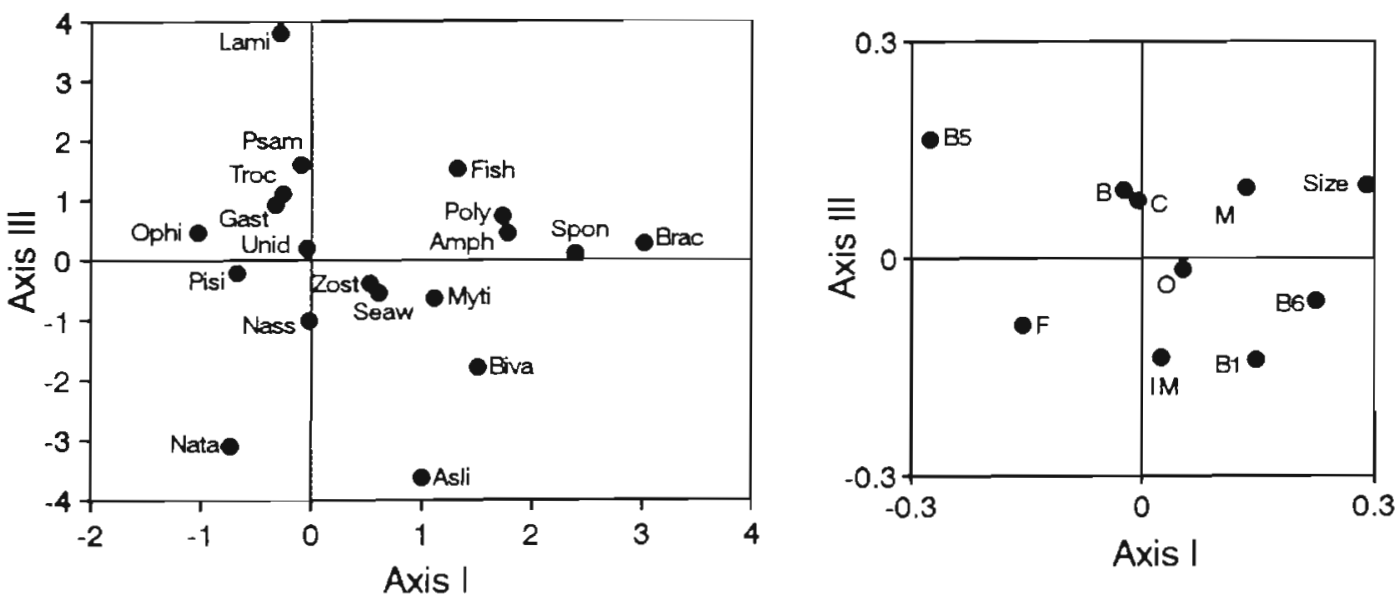

Fig. 5. Necora puber. Distribution of prey and 'external vaniables' (size; sex: $M, F, O$; station: B1, B5, B6; and intermoult cycle stage: $B, C, I M$ ) on the first 3 axes extracted from the CCA (prey codes are given in Table 1); see 'Materials and methods' for sex and intermoult stages

Table 5. Necora puber. Parameters of the allometric equation, $\log _{10}($ Food dry weight $)=\log _{10} a+b \log _{10} C W$, fitted for each station, sex and intermoult cycle stage and for specimens having maximum repletion (points index $=100)$. Regression coefficient $\left(R^{2}\right)$, number of crabs $(\mathrm{N})$ and significance level $(\mathrm{p})$ are shown. The equations were fitted using data from crabs having food in their stomachs

\begin{tabular}{|c|c|c|c|c|c|}
\hline & $\log a(S E)$ & $b(\mathrm{SE})$ & $\mathrm{R}^{2}$ & $p$ & $\mathrm{~N}$ \\
\hline \multicolumn{6}{|l|}{ Station } \\
\hline B1 & $-3.922(0.676)$ & $1.360(0.378)$ & 0.091 & 0.001 & 132 \\
\hline B5 & $-3.724(0.393)$ & $1.265(0.228)$ & 0.074 & $<0.001$ & 386 \\
\hline B6 & $-3.826(0.967)$ & $1.365(0.543)$ & 0.103 & 0.015 & 57 \\
\hline \multicolumn{6}{|l|}{ Sex } \\
\hline Males & $-3.765(0.391)$ & $1.272(0.223)$ & 0.094 & $<0.001$ & 313 \\
\hline Non-ovigerous females & $-4.043(0.507)$ & $1.473(0.293)$ & 0.092 & $<0.001$ & 252 \\
\hline Ovigerous females & $1.821(5.597)$ & $-1.837(3.052)$ & 0.024 & 0.556 & 17 \\
\hline \multicolumn{6}{|l|}{ Intermoult cycle stage } \\
\hline B & $-4.575(0.858)$ & $1.715(0.492)$ & 0.099 & 0.001 & 113 \\
\hline C & $-4.775(0.876)$ & $1.988(0.500)$ & 0.178 & $<0.001$ & 75 \\
\hline $\mathrm{IM}$ & $-3.366(0.338)$ & $1.047(0.194)$ & 0.070 & $<0.001$ & 391 \\
\hline $\begin{array}{l}\text { Maximum fullness } \\
\text { (Points index }=100)\end{array}$ & $-4.34 \perp(0.530)$ & $1.956(0.306)$ & 0.383 & $<0.001$ & 68 \\
\hline
\end{tabular}


in fullness were found between the different intermoult stages and seasons (ANCOVA; covariate effect: predator size, $p>0.1$ for analyses including crabs without food and $p<0.001$ for analyses restricted to crabs with food; intermoult stage, $\mathrm{p}<0.001$ for both analyses; season, $\mathrm{p}>0.01$ for gut fullness $\geq 0$ and $p<0.05$ for fullness $>0$ ); this, however, was not the case between stations or sexes $(p>0.1)$. Stn B5 had a lower percentage of empty stomachs $(31.4 \%)$ than Stn B1 (41.2\%) or Stn B6 (46.4\%); however, fullness levels are quite similar in the different areas studied. The BDW index at Stn B5 was higher than at Stns B1 and B6, since the mean size of the crabs caught and analyzed at Stn B5 (males: $57.2 \mathrm{~mm} \mathrm{CW}, \mathrm{SD}=14.6$; females: $53.8 \mathrm{~mm} \pm 11.3$ ) was lower than at Stn B1 (males: $66.6 \mathrm{~mm} \pm 15.1$; females: $61.4 \mathrm{~mm} \pm 10.9$ ) and at Stn B6 (males: $66.1 \mathrm{~mm} \pm 15.1$; females: $57.1 \mathrm{~mm} \pm 11.1$ )

The stomach fullness appeared lower in the case of ovigerous females, although because of the small sample size this could not be verified, and similar between males and non-ovigerous females, although the latter always presents slightly higher values (Fig. 6). The changes in fullness in females appear to be linked to the reproductive cycle, showing a drop throughout the maturation process. The differences in fullness observed during the intermoult cycle point to the existence of 4 clearly defined periods of feeding activity (Fig. 6). In the stages immediately before and after ecdysis (stages D and A respectively) there was practically no ingestion of food $196 \%$ and $95 \%$, respectively, of the crabs analyzed had empty stomachs). Food consumption began after ecdysis during stage B (28.5\% of the stomachs were empty), and increased during intermoult period C $119.8 \%$ empty stomachs), to decrease to lower levels in stage IM (38\% empty stomachs). There were important seasonal changes in food consumption which were reflected in an increase in stomach fullness in autumn and especially in winter (Fig. 6), with low values in July and August.

\section{Predation on infauna and raft epifauna: prey selection}

From a functional point of view, different groups of prey can be distinguished among the benthos and organisms associated with mussel culture (Fig. 7). The raft epifauna and the mussel made up the dominant group
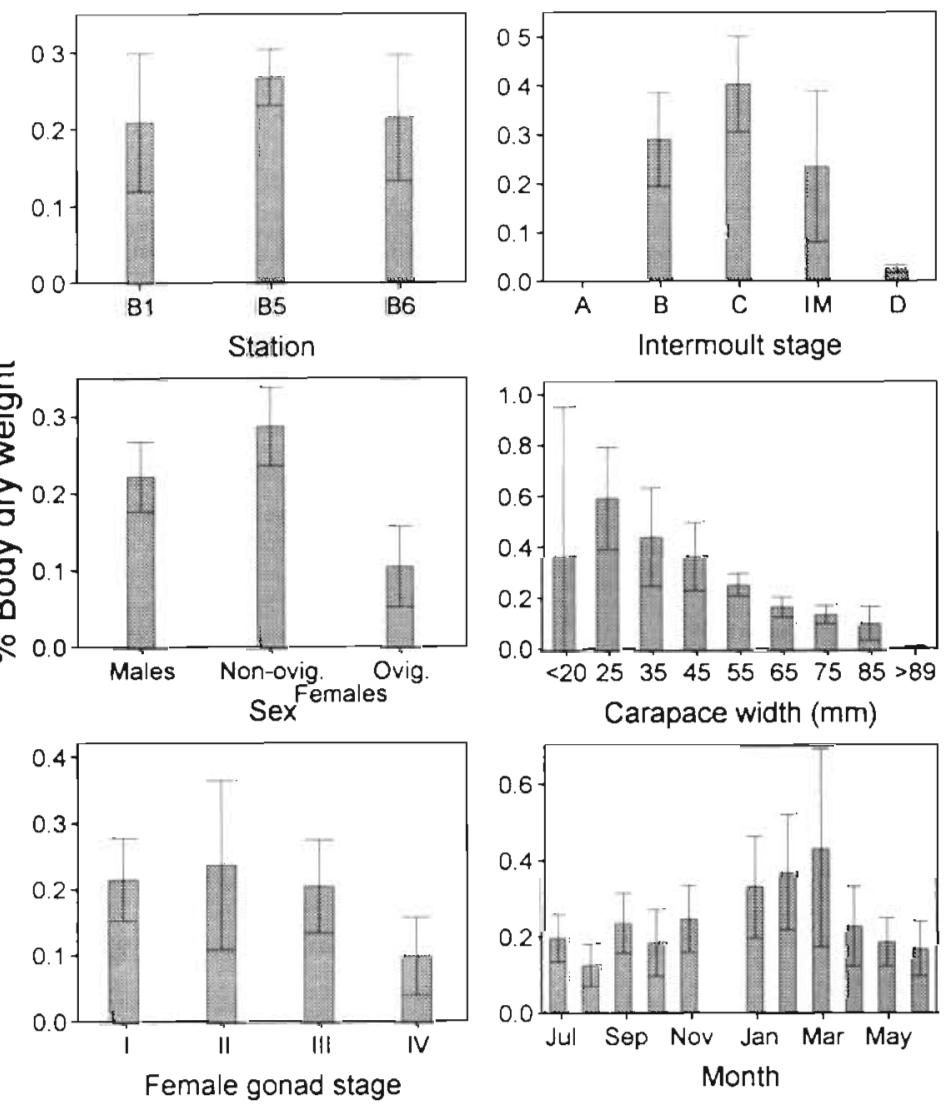

Fig. 6. Necora puber. Stomach fullness (mean and $95 \%$ confidence interval of the BDW index are shown) for the different sampling stations, sexes, stage of gonad development in females, intermoult cycle stage, body size, and monthly evolution throughout the yearly cycle

of prey in the diet of Necora puber. Spatial differences did exist, however, with these organisms showing maximum importance in the diet at Stns B1 and B5 (>80\% BDW), while at Stn B6 predation on the epifauna and mussel decreased to approximately $50 \%$. Macroinfauna

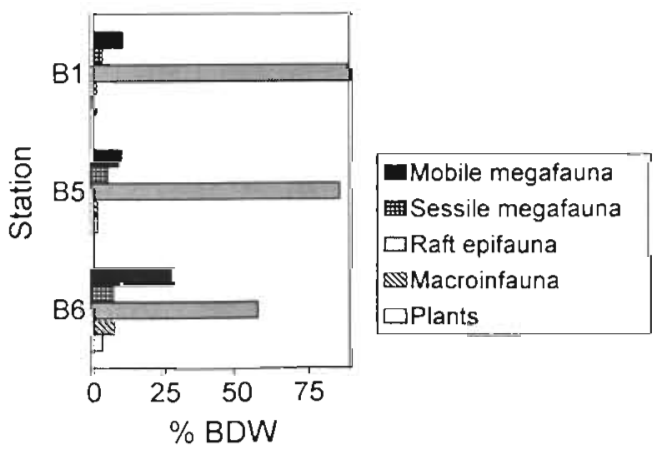

Fig. 7. Necora puber. Diet composition at the different sampling stations located in the Ria de Arousa. Original prey are grouped in terms of habitat, biological characteristics and mobility 
Outer area - Station B5
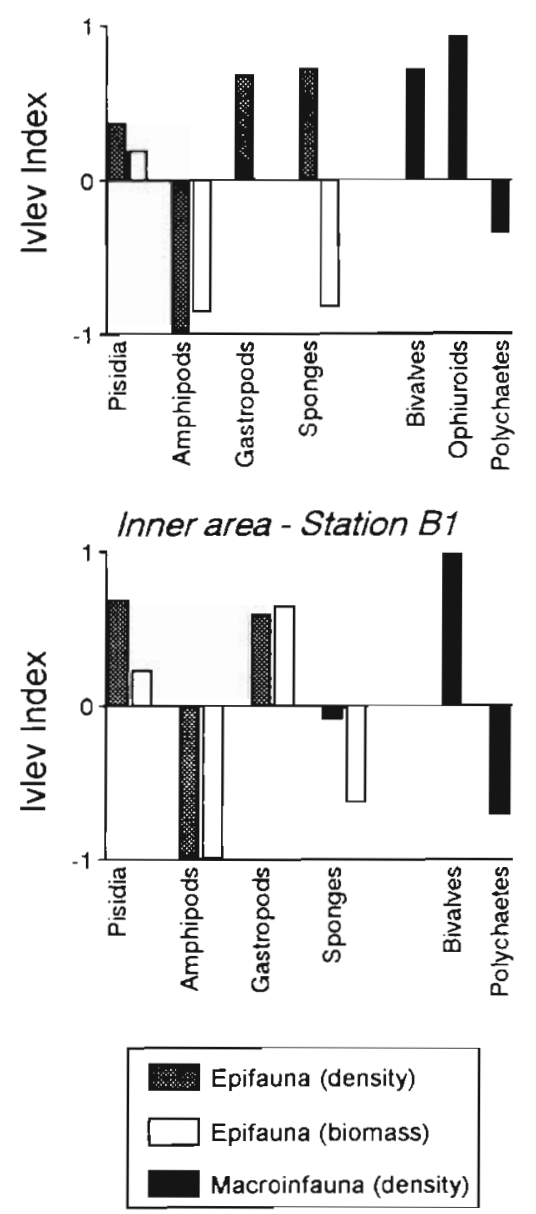

Fig. 8. Necora puber. lvlev index of prey selection at Stns B1 (inner ría area) and B5 (outer area). Selection indices are calculated independently for the part of the diet corresponding to epifauna and infauna in terms of importance in the stomach contents of the different prey and their density or biomass in infauna (data from López-Jamar 1982) and epifauna (data from Román \& Pérez 1982)

constituted only between 2 and $7 \%$ of the diet at the different stations, while meiofauna did not constitute part of the diet in any of the areas studied. Within the benthic megafauna, 2 groups of prey can be distinguished in terms of mobility: sessile or with little mobility (holothuroids and echinoids) and mobile species (fishes and decapods). The consumption of megafauna was greater at Strns B6 and B1 (36 and 18\% respectively) than at Stn B5 (15\%) following a pattern opposite to that of the epifauna of the culture.

Prey selection patterns were analyzed using data from Román \& Pérez (1982) and López-Jamar (1982) for epifauna and infauna respectively, relating to the mid-outer areas (Stn B5) and the inner zone (Stn B1) in the Ría de Arousa. Annual mean density and biomass were obtained from epifaunal samples taken from the ropes used for thinning out and seeding by Román \& Pérez (1982) and the 4 dominant groups in the diet or in the epifaunal community were analyzed (Pisidia longicornis, amphipods, gastropods and sponges). Data from López-Jamar (1982) on density of infauna allowed us to analyze the selection of polychaetes, bivalves (except mussel) and ophiuroids, which are the most important components of the benthic macroinfauna in the Ría de Arousa. In general, prey selection patterns were similar in the inner and outer zones (Fig. 8). Among the epifauna, the Ivlev index presented positive values for $P$. longicornis at both stations, especially using density data. The other dominant group within the epifauna is the amphipods, which were selected negatively. Gastropods and sponges are unimportant taxa in the diet, but they are somewhat important in the epifaunal community, especially in density in the case of the gastropods and biomass in the sponges. The gastropods had positive values of the Ivlev index; however, the selection pattern that sponges followed was much more variable. Within the groups of benthic macroinfauna analyzed, the ophiuroids were important, both in the diet and field, only in the mid-outer zone, whereas the polychaetes as well as the bivalves were the dominant groups in both areas. Necora puber had a positive selection for bivalves and ophiuroids and negative for polychaetes both at Stns B1 and B5.

\section{DISCUSSION}

Necora puber has a generalist diet which is determined in the first place by the structure of the prey community and secondly, by the selection of available prey. In general, portunid crabs have unspecialized diets that reflect the taxonomic composition and structure of the potential prey communities, mainly macroinvertebrates (molluscs and crustaceans) sessile or with little mobility (Hill 1976, 1979, Paul 1981, Williams 1981, Laughlin 1982, Wear \& Haddon 1987, Ropes 1988, Abellô 1989, Edgar 1990, Haefner 1990, Hines et al. 1990, Stoner \& Buchanan 1990, Hsueh et al. 1992) The spatial variability in the availability of prey has been identified as the primary cause of the changes in the trophic relationships of decapod crustaceans (Paul 1981, Alexander 1986. Wear \& Haddon 1987, González-Gurriarán et al. 1989, Edgar 1990, Freire et al. 1990). The habitats sampled in the Ría de Arousa show differences in the abundance and structure of the benthic communities (González-Sanjurjo 1982, LópezJamar 1982, Román \& Pérez 1982), which is the reason that the spatial changes are the most important factor in the variability of diet composition in $N$. puber The 
distribution of Pisidia longicornis in the ría (GonzálezSanjurjo 1982, Román \& Pérez 1982, Fernández et al. 1990), with maximum densities in the mid-outer zones (Stn B5) and the sharp drops in the inner area (Stn B1), determines spatial changes in its importance in the diet of $N$. puber.

Studies carried out on the feeding of Necora puber in the south of England (Norman \& Jones 1992) and Wales (Choy 1986) analyzed populations located in rocky inter- and subtidal zones, whereas our research concentrates on soft bottom habitats located in the mussel culture areas. In the rocky zones, the diet is dominated by brown seaweeds, crustaceans (Brachyura and barnacles), bivalves and gastropods. The major differences that were observed between the diet on the coasts of Galicia and in the British Isles appear to be linked more to differences in prey availability between habitats than to geographical changes. In keeping with this, Norman \& Jones (1992) suggest that there are major changes in the diet with depth, which implies that the velvet swimming crab decreases its consumption of seaweeds and tends to feed more on benthic invertebrates with increasing depth. In the mussel culture areas, $N$. puber preys chiefly on the raft epifauna and megafauna, with plants and macrofauna providing a secondary source of food. Although herbivory is more widespread among the family Majidae (Wolcott \& O'Connor 1992), enzymes specific to the digestion of reserve carbohydrates found in different groups of seaweeds have also been detected in portunid species such as Callinectes sapidus (McClintock et al. 1991) and $N$. puber (Norman \& Jones 1990). In spite of this, both Choy (1986) and Norman \& Jones (1992) suggest that the importance of the seaweeds in the diet of $N$. puber is due to their abundance in the area studied, although $N$. puber prefers animal prey. Similarly, $C$. sapidus feeds mainly on invertebrates and fishes (Hines et al. 1990) even though it is capable of producing carbohydrases.

Several studies on the diet of decapods highlight ontogenetic changes as the most important biotic factor in diet variability. During growth, crabs increase the consumption of fishes and decapods (especially Brachyura) and sharply reduce the predation on nondecapod crustaceans and plants (Paul 1981, Stevens et al. 1982, Stoner \& Buchanan 1990, Hsueh et al. 1992). In the Ría de Arousa the ontogenetic evolution in the diet of Necora puber is similar to that described for other species of Brachyura. We observed an increase in the consumption of fishes, Brachyura and molluscs (especially mussels) with size, whereas Pisidia longicornis and non-decapod crustaceans follow the opposite trend. In general, an increase in the predator's body size means that the prey size will increase, with the predator feeding more on prey having hard exo- skeletons in relation to the ontogenetic changes in the biomechanical characteristics of the chelipeds and mechanisms for the selection of the prey (ap Rheinallt \& Hughes 1985, ap Rheinallt 1986, Freire unpubl. data)

Decapods do not generally show any significant differences in diet composition between the sexes (Wear \& Haddon 1987, Haefner 1990, Hsueh et al, 1992). Necora puber only exhibits slight differences in diet between males and females, and they may be attributed to the greater body size of the males, as the changes linked to growth are similar to the differences observed between males and females. Norman \& Jones (1992) report that sexual differences in the diet are due only to the breeding cycle, during which time ovigerous females reduce their predation activity. In the Ría de Arousa, female stomach fullness decreases during the breeding cycle and in advanced stages of gonad development.

The intermoult cycle brings about drastic changes in the feeding activity of the Brachyura. They cease their intake of food in the immediate pre- and post-ecdysis stages, and increase stomach repletion in the recent postmoult stages (Abelló \& Cartes 1987, O'Halloran \& O'Dor 1988, Abelló 1989, Norman \& Jones 1992). This study reports on the changes in the consumption of different prey that Necora puber undergoes during the intermoult cycle, and highlights the increased consumption of Pisidia longicornis, fishes and plants in the early post-ecdysis stages (the consumption of fishes in the early postmoult stage may correspond to necrophagous activity). These changes are determined chiefly by the decreased capacity for predation during the early postmoult stages, which causes a greater consumption of plants and sedentary prey, and by the calcium required to form the new carapace that may be supplied by the different skeletal structures of the prey organisms (Abelló \& Cartes 1987).

The epifauna are the dominant prey in the stomach contents of the portunids in the raft areas of the Ría de Arousa, making up very high percentages of the food consumed (reaching over $80 \%$ in the case of Necora puber) (González-Gurriarán et al. 1989, Freire et al. 1990, Freire 1993). These results correspond to the high biomass that these organisms reach on the 3-dimensional support consisting of the culture ropes (González-Sanjurjo 1982, Román \& Pérez 1982, Fernández et al. 1990). The mussel and epifauna that detach from the ropes as a result of weather conditions or human activity carried out on the raft (Pérez \& Román 1979) facilitate the availability of these prey for the epibenthos. In addition, the portunids have direct access to the culture ropes because the crabs are able to swim (Hartnoll 1971), because they can gain access by means of the anchoring points, and also because the 
ropes occasionally touch the bottom at low tides. The fact that the infauna is of little importance in the diet of $N$. puber in the raft stations may be attributed to the decrease in abundance and biomass that is observed both in the Ría de Arousa, compared to other rías, and within this ria, in the raft zones, as compared to areas that are not devoted to culture (López-Jamar 1982, Tenore et al. 1982, López-Jamar \& Mejuto 1986). However, the megafauna has higher densities and biomass in the raft areas (demersal fishes and echinoderms as well as decapod crustaceans) (Chesney \& Iglesias 1979, Iglesias 1981, González-Gurriarán 1982, Olaso 1982, Romero et al. 1982). In spite of its abundance, $N$. puber has a limited ability to prey on this group of organisms, as its mobility and size make it difficult for this crab to capture and handle these prey (ap Rheinallt \& Hughes 1985, ap Rheinallt 1986). According to this, although the megafauna are an important part of the diet, it does not come close to the levels reached by the more accessible, and probably more abundant, epifaunal prey in the culture polygons.

The prey selection patterns seen in Necora puber are similar to those observed in other portunid species (Freire 1993) and demersal fishes (López-Jamar et al. 1984) in the mussel culture areas of the Ría de Arousa. Within the epifauna there is a positive selection on the species having the greatest biomass in the community, Pisidia longicornis, and negative for the amphipods, which also reach high densities (González-Sanjurjo 1982, Román \& Pérez 1982). Of the infauna, the polychaetes, which are dominant in density and biomass (López-Jamar 1982, Tenore et al. 1982, López-Jamar \& Mejuto 1986), are of proportionally small importance in the diet. Both the ophiuroids and bivalves, which are less abundant groups within the benthic macrofauna, are selected positively.

The temporal changes in the epifaunal community are determined by both environmental seasonality and the succession that is established after the mussel seed is placed in the sea or after thinning out (which means that the associated epifauna is eliminated). Since these processes have a strong temporal variability (PérezCamacho et al. 1991), ropes in different stages of culture exist throughout the year, which makes the seasonal pattern more complex. For this reason, the diet and availability of the different groups of epifauna do not undergo major seasonal fluctuations.

Mussel culture on rafts brings about different changes in the ecosystem which directly affect the benthic megafauna. On the one hand, the bottoms of the culture areas are structurally complex, giving rise to shelters and microhabitats for the megabenthic organisms. Food is also more widely available, due to the appearance of new prey communities such as the epifauna or the cultured mussel itself. These are the factors which cause the population dynamics of the decapods in the Ría de Arousa to be linked to the raft areas (González-Gurriarán 1982, 1985a, b, Romero et al. 1982, Fernández et al. 1991, Freire et al. 1991). There is an increase in density and biomass, growth rates and the secondary production of different species and of the community as a whole in the raft areas, as compared to other habitats. Also, species such as $\mathrm{NeC}$ ora puber carry out seasonal migrations towards the culture areas (González-Gurriarán 1981, 1985a, b). In contrast, demersal fishes are more mobile than the decapods, which is why it has been suggested that they have different feeding and habitat selection strategies, even though they feed on the raft epifauna. The teleost species which are dominant in the Ría de Arousa do not show differences in abundance between habitats (Chesney \& Iglesias 1979, Iglesias 1981) since they have access to the raft polygons for feeding from other areas (López-Jamar et al. 1984).

Acknowledgements. This research was funded by the Consellería de Pesca, Marisqueo e Acuicultura of the Xunta de Galicia through FEUGA. We thank J. Parapar, I. Bárbara, J. Troncoso, V. Urgorri, M. Rodríguez-Solórzano and J. Mora for their collaboration in the identification of different taxonomic groups in stomach contents, and 2 anonymous referees for their comments that improved the manuscript. J.F. held a fellowship from the Ministerio de Educación y Ciencia (Plan de Formacion de Personal Investigador) during this study

\section{LITERATURE CITED}

Abelló, P. (1989). Feeding habits of Macropipus tuberculatus (Brachyura, Portunidae) off the Catalan coast (NW Mediterranean). Misc. Zool. 13: 45-50

Abelló, P., Cartes, J. (1987). Observaciones sobre la alimentación ce Liocarcinus depurator (L.) (Brachyura: Portunidae) en el Mar Catalán. Invest. Pesq. 51(Suppl. 1): 413-419

Alexander, S. K. (1986). Diet of the blue crab, Callinectes sapidus Rathbun, from nearshore habitats of Galveston Island, Texas. Texas J. Sci. 38: 85-89

ap Rheinallt, I (1986). Size selection by the crab Liocarcinus puber feeding on mussels Mytilus edulis and on shore crabs Carcinus maenas: the importance of mechanical factors. Mar. Ecol. Prog. Ser. 29: 45-53

ap Rheinallt, T., Hughes, R. N. (1985). Handling methods used by the velvet swimming crab Liocarcinus puber when feeding on molluscs and shore crabs. Mar. Ecol. Prog. Ser. 25: $63-70$

Aronson, R. B. (1989). Brittlestar beds: low-predation anachronisms in the British Isles. Ecology 70: 856-865

Aronson, R. B. (1992). Biology of a scale-independent predator-prey interaction. Mar. Ecol. Prog. Ser. 89: 1-13

Chesney, E. J. Jr, Iglesias, J. (1979). Seasonal distribution, abundance and diversity of demersal fishes in the inner Ría de Arosa, Northwest Spain. Estuar. coast, mar. Sci. 8: $227-239$

Choy, S. C. (1986). Natural diet and feeding habits of the crabs Liocarcinus puber and L. holsatus (Decapoda, Brachyura, Portunidae). Mar. Ecol. Prog. Ser. 31: 87-99

Choy, S. C. (1988). Reproductive biology of Liocarcinus puber and L. holsatus (Decapoda, Brachyura, Portunidae) from 
the Gower Peninsula, South Wales. P.S.Z.N. I: Mar. Ecol. 9: 227-241

Corral, J., Alvarez-Ossorio, M. T. (1978). El zooplancton de la Ría de Arousa (NW de España). I. Composición y distribución de las comunidades en un ciclo anual. Boln Inst. Esp. Oceanogr. 4(265): 131-163

Drach, P., Tchernigovtzeff, C. (1967). Sur le méthode de détermination des stades d'intermue et son aplication générale aux Crustacés. Vie Milieu 18: 595-609

Edgar, G. J. (1990). Predator-prey interactions in seagrass beds. II. Distribution and diet of the blue manna crab Portunus pelagicus Linnaeus at Cliff Head, Western Australia. J. exp. mar. Biol. Ecol. 139: 23-32

Fernández, L., González-Gurriarán, E., Freire, J. (1991). Population biology of Liocarcinus depurator (Brachyura: Portunidae) in mussel raft culture areas in the Ría de Arousa (Galicia NW Spain). J. mar. biol. Ass. U.K. 71: 375--390

Fernández, L., González-Gurriarán, E., Freire, J., Muiño, R. (1990). Abundancia y distribución de Pisidia longicornis (Linnaeus, 1767) (Decapoda, Anomura) en relación con la dinámica del cultivo de mejillón en la Ría de Arousa (Galicia, NW España). Boln R. Soc. Española Hist. Nat. (Biol.) 86: $181-193$

Freire, J. (1993). Alimentación de los crustáceos decápodos (Brachyura) en la Ría de Arousa: influencia del cultivo de mejillon. Ph.D. thesis, Univ. A Coruna

Freire, J., Fernández, L., González-Gurriarán, E. (1990). Influence of mussel raft culture on the diet of Liocarcinus arcuatus (Leach) (Brachyura: Portunidae) in the Ría de Arousa (Galicia, NW Spain). J. Shellfish Res. 9: 45-57

Freire, J., Muiño, R., Fernández, L., González-Gurriarán, E. (1991). Life cycle of Liocarcinus arcuatus (Brachyura: Portunidae) in the Ría de Arousa (Galicia, NW Spain): role of beach and mussel raft culture areas. P.S.Z.N. I: Mar. Ecol. 12: $193-210$

González-Gurriarán, E. (1978). Introducción al estudio de la alimentación en la nécora, Macropipus puber L. (Decapoda-Brachyura). Boln Inst. Esp. Oceanogr. 4(242): 81-93

González-Gurriarán, E. (1981). Preliminary data on the population dynamics of the velvet swimming crab (Macropipus puber L.) in the Ría de Arousa (Galicia, NW Spain). Comm. Meet. int. Coun. Explor. Sea C.M.-ICES 1981/ K: $16: 1-21$

González-Gurriarán, E. (1982). Estudio de la comunidad de crustáceos decápodos (Brachyura) en la Ría de Arousa (Galicia-NW España), y su relación con el cultivo de mejillón en batea. Boln Inst. Esp. Oceanogr. 7: 223-254

González-Gurriarán, E. (1985a). Reproducción de la nécora Macropipus puber (L.) (Decapoda, Brachyura), y ciclo reproductivo en la Ría de Arousa (Galicia, NW España). Boln Inst. Esp. Oceanogr. 2: 10-32

González-Gurriarán, E. (1985b). Crecimiento de la nécora Macropipus puber (L.) (Decapoda, Brachyura) en la Ría de Arousa (Galicia, NW España), y primeros datos sobre la dinámica de la población. Boln Inst. Esp. Oceanogr. 2: $33-51$

González-Gurriarán, E., Freire, J., Fernández, L., Poza, E. (1989). Incidencia del cultivo de mejillón en la dieta de Liocarcinus depurator (L.) (Brachyura: Portunidae) en la Ría de Arousa (Galicia, NW España). Cah. Biol. mar. 30: $307-319$

González-Gurriarán, E., Méndez, M. (1985). Crustáceos decápodos das costas de Galicia. Cuad. Area Cienc. Biol., Semin. Estud. Galegos 2: 1-242

González-Sanjurjo, R. (1982). Estudio de la epifauna de la semilla de mejillón en la Ría de Arousa. Boln Inst. Esp. Oceanogr. 7(336): 49-71
Haefner, P. A. Jr (1990). Natural diet of Callinectes ornatus (Brachyura: Portunidae) in Bermuda. J. Crust. Biol. 10: $236-246$

Hartnoll, R. G. (1971). The occurrence, methods and significance of swimming in the Brachyura. Anim. Behav. 19: $34-50$

Hill, B. J. (1976). Natural food, foregut clearance-rate and activity of the crab Scylla serrata. Mar. Biol. 34: 109-116

Hill, B. J. (1979). Aspects of the feeding strategy of the predatory crab Scylla serrata. Mar. Biol. 55: 209-214

Hines, A. H., Haddon, A. M., Wiechert, L. A. (1990). Guild structure and foraging impact of blue crabs and epibenthic fish in a subestuary of Chesapeake Bay. Mar. Ecol. Prog. Ser. 67: 105-126

Hsueh, P.-W., McClintock, J. B., Hopkins, T. S. (1992). Comparative study of the diets of the blue crabs Callinectes similis and $C$. sapidus from a mud-bottom in Mobile Bay, Alabama. J. Crust. Biol. 12: 615-619

Iglesias, J. (1981). Spatial and temporal changes in the demersal fish community of the Ría de Arosa (NW Spain). Mar. Biol. 65: 199-208

Ivlev, V. S. (1961). Experimental ecology of the feeding of fishes. Yale University Press, New Haven

Kingston, J. C., Birks, H. J. B., Uutala, A. J., Cumming, B. F., Smol, J. P. (1992). Assessing trends in fishery resources and lake water aluminum from paleolimnological analyses of siliceous algae. Can J. Fish. Aquat. Sci. 49: 116-127

Kitching, J. A., Sloane, J. F., Ebling, F. J. (1959). The ecology of Lough Ine. VIII. Mussels and their predators. J. Anim. Ecol. 28: 331-341

Lapointe, B. E., Niell, F. X., Fuentes, J. M. (1981). Community structure, succession, and production of seaweeds associated with mussel-rafts in the Ría de Arosa, N.W. Spain. Mar. Ecol. Prog. Ser. 5: 243-253

Laughlin, R. A. (1982). Feeding habits of the blue crab, Callinectes sapidus Rathbun, in the Apalachicola Estuary, Florida. Bull. mar. Sci. 32: 807-822

López-Jamar, E. (1982). Distribución espacial de las comunidades bentónicas infaunales de la Ría de Arosa. Boln Inst. Esp. Oceanogr 7(347): 255-268

López-Jamar, E., Iglesias, J., Otero, J. J. (1984). Contribution of infauna and mussel-raft epifauna to demersal fish diets. Mar. Ecol. Prog. Ser. 15: 13-18

López-Jamar, E., Mejuto, J. (1986). Evolución temporal de cuatro comunidades infaunales de las Ría de Arosa y Muros. Resultados preliminares. Boln Inst. Esp. Oceanogr. 3: $95-110$

Magurran, A. E. (1989). Ecological diversity and its measurement. Princeton Univ. Press, Princeton, NJ

McClintock, J., Klinger, T. S., Marion, K., Hsueh, P. (1991). Digestive carbohydrases of the blue crab Callinectes sapidus (Rathbun): implications in utilization of plantderived detritus as a trophic resource. J. exp. mar. Biol. Ecol. 148: 233-239

Muntz, L., Ebling, F. J., Kitching, J. A. (1965). The ecology of Lough Ine. XIV. Predatory activity of large crabs. J. Anim. Ecol. 34: 315-329

Norman, C. P., Jones, M. B. (1990). Utilisation of brown algae in the diet of the velvet swimming crab Liocarcinus puber (Brachyura: Portunidae). In: Barnes, M., Gibson, R. N. (eds.) Trophic relationships in the marine environment. Proc. 24th Eur. Mar. Biol. Symp. Aberdeen University Press, Aberdeen, p. 491-502

Norman, C. P. Jones, M. B. (1992). Influence of depth, season and moult stage on the diet of the velvet swimming crab Necora puber (Brachyura, Portunidae). Estuar. coast. Shelf Sci. 34: 71-83 
O'Halloran, M. J., O'Dor, R. K. (1988). Molt cycle of male snow crabs, Chionoecetes opilio, from observations of external features, setal changes, and feeding behavior. J. Crust. Biol 8: 164-176

Olaso, I. (1982). Ecología de los equinodermos de la Ría de Arosa. Boln Inst. Esp. Oceanogr. 7(334): 3-29

Paul, R. K. G. (1981). Natural diet, feeding and predatory activity of the crabs Callinectes arcuatus and $C$. toxotes (Decapoda, Brachyura, Portunidae). Mar. Ecol. Prog. Ser. 6: $91-99$

Pérez, A., Román, G. (1979). Estudio del mejillón y de su epifauna en los cultivos flotantes de la Ría de Arousa. II. Crecimiento, mortalidad y producción del mejillón. Boln Inst. Esp. Oceanogr. 5: 23-41

Pérez-Camacho, A., González, R., Fuentes, J. (1991). Mussel culture in Galicia (N.W. Spain). Aquaculture 94: 263-278

Román, G., Pérez, A. (1982). Estudio del mejillón y de su epifauna en los cultivos flotantes de la Ría de Arosa. IV. Evolución de la comunidad. Boln Inst. Esp. Oceanogr. 7(349): 279-296

Romero, P., González-Gurriarán, E., Penas, E. (1982). Influence of mussel rafts on spatial and seasonal abundance of crabs in the Ría de Arousa, North-West Spain. Mar. Biol. 72: $201-210$

Ropes, J. W. (1988). The food habits of five crab species at Pettaqquamscutt River, Rhode Island. Fish. Bull. U.S. 87: $197-204$

Smaal, A. C. (1991). The ecology and cultivation of mussels: new advances. Aquaculture 94: 245-261

Stevens, B. G., Armstrong, D. A., Cusimano, R. (1982). Feeding habits of the Dungeness crab Cancer magister as determined by the Index of Relative Importance. Mar Biol. 72: 135-145

Stoner, A. W., Buchanan, B. A. (1990). Ontogeny and overlap in the diets of four tropical Callinectes species. Bull. mar. Sci. $46: 3-12$

Tenore, K. R., Boyer, L. F., Cal, R. M., Corral, J., GarcíaFernández, C., González, N., González-Gurriarán, E.,

This article was submitted to the editor
Hanson, R. B., Iglesias, J., Krom, M., López-Jamar, E., McClain, J., Pamatmat, M. M., Pérez, A., Rhoads, D. C. Santiago, G., Tietjen, J., Westrich, J., Windom, H. L. (1982). Coastal upwelling in the Rías Bajas, NW Spain: contrasting the benthic regimes of the Rías de Arousa and de Muros. J. mar. Res. 40: 701-772

Ter Braak, C. J. F. (1986). Canonical correspondence analysis: a new eigenvector technique for multivariate direct gradient analysis. Ecology 67: 1167-1179

Ter Braak, C. J. F. (1987). Partial correspondence analysis. In: Ter Braak, C. J. F. (ed.) Unimodal models to relate species to environment. Agricultural Mathematics Group, Wageningen, p. 83-91

Ter Braak, C. J. F. (1988). CANOCO - a FORTRAN program for canonical ordination by [partial] [detrended] [canonical] correspondence analysis, principal component analysis and redundancy analysis. Agricultural Mathematics Group, Wageningen

Ter Braak, C. J. F, Prentice, I. C. (1988). A theory of gradient analysis. Adv. Ecol. Res. 18: 101-146

Veer, H. W. van der (1989). Eutrophication and mussel culture in the western Dutch Wadden Sea: impact on the benthic ecosystemi a hypothesis. Helgoländer Meeresunters. 43: $517-527$

Walker, I. R., Smol, J. P., Enfstrom, D. R., Birks, H. J. B. (1991). An assessment of Chrironomidae as quantitative indicators of past climatic change. Can. J. Fish. Aquat. Sci. 48: 975-987

Wear, R. G., Haddon, M. (1987). Natural diet of the crab Ovalipes catharus (Crustacea, Portunidae) around central and northern New Zealand. Mar. Ecol. Prog. Ser. 35: $39-49$

Williams, M. J. (1981). Methods for analysis of natural diet in portunid crabs (Crustacea: Decapoda: Portunidae). J. exp. mar. Biol. Ecol. 52: 103-113

Wolcott, D. L., O'Connor, N. J. (1992). Herbivory in crabs: adaptations and ecological considerations. Am. Zool. 32: $370-381$

Manuscript first received: July 14, 1994

Revised version accepted: January 3, 1995 


\title{
Amino acid and related compound composition in two symbiotic mytilid species from hydrothermal vents
}

\author{
V. Pranal, A. Fiala-Médioni, J. C. Colomines \\ Observatoire Océanologique, laboratoire ARAGO, Université Pierre et Marie Curie - CNRS URA 117, \\ F-66650 Banyuls-sur-mer, France
}

\begin{abstract}
Two species of deep-sea mussels belonging to the genus Bathymodiolus were collected from 5 vent fields distributed over 2 basins of a hydrothermal system in the South Pacific. Free and bound primary amino compounds were analysed in gills and mantles using OPA-HPLC. The method allowed the detection of 32 amino acids and related compounds (AARCs). An undetermined free chemical was found at high levels (up to $30 \%$ of the total free AARCs) in vent mussel tissues. This amino compound is presumed to be an end-product from specific metabolism occurring in vent mussels. Except for this unknown compound, comparison of the biochemical composition between vent and littoral mussels revealed that the general nitrogenous requirement as well as the endogenous metabolic pathways of the main amino acids seem to be similar for the 2 mussel types. Ultrastructural observations indicated that these deep mussels harbour bacteria in their gills. Indices of high metabolic rates found in these organs appear to be related to the presence of endobacterial. It seems that symbionts could provide a preponderant fraction of essential amino acids to their host. In particular, free thiotaurine displayed high concentrations (up to $13 \%$ of the total free AARCs). This sulphur-containing compound could be involved in a specific metabolism related to toxic forms of sulphur. Variations of the AARC composition between the 2 vent mussel species do not appear to be species related but appear to be due to environmental constraints. As shown by stress indices, deterioration of the physiological condition in these mussels is directly linked to the quantity and/or the quality of the hydrothermal vent emissions.
\end{abstract}

KEY WORDS: Amino acids and related compounds - Symbiotic mussels · Sulphur-oxidizing bacteria * Hydrothermal vent . Physiological index

\section{INTRODUCTION}

The bivalves Mytilidae have a world-wide distribution with a great majority of species occurring intertidally in littoral and shallow sublittoral ecosystems (Russell-Hunter 1983, Koehn 1991). This family, like most other marine invertebrates, depends for its food supplies on the phytoplanktonic primary production that constitutes the base of the general marine foodweb (Jørgensen 1990). Until recently, mussels were considered to be exclusively sedentary, filter-feeding organisms living on plankton and organic detritus (Bayne 1976, Allen 1983), free bacteria (Prieur 1981, Birkbeck \& McHenery 1982) or dissolved organic solutes (Stephens 1972, Melaouah 1990). Discovery of a new fauna associated with deep hydrothermal vents has shown that at least 1 genus, Bathymodiolus, can use another nutritional strategy (Fiala-Médioni et al. 1986a, Fiala-Médioni \& Le Pennec 1987, Fiala-Médioni 1988). Species of this genus were found associated with deep, active tectonic areas in the Atlantic and Pacific (Fiala-Médioni 1988). These environments, which often correspond to the aphotic zone, are depleted of photosynthetic carbon but are full of energy-rich chemicals and sometimes highly toxic substances like hydrogen sulphide $\left(\mathrm{H}_{2} \mathrm{~S}\right)$ or heavy metals (Childress \& Fisher 1992). All of the Bathymodiolus species critically examined to date harbour autotrophic prokaryotes in their gill cells. These bacteria appear to be able to use sulphur or methane to power carbon fix- 